\title{
Paramedian chest wall dermoid cyst
}

\author{
Mohamed Maklad, ${ }^{1}$ Elise Gradhand, ${ }^{2}$ Emily West ${ }^{2}$
}

${ }^{1}$ Plastic Surgery, Bristol Children Hospital, Bristol, UK

${ }^{2}$ Pathology and Plastic Surgery, North Bristol NHS Trust, Westbury on Trym, Bristol, UK

\section{Correspondence to}

Mr Mohamed Maklad mohamedmaklad@doctors. org.uk

Accepted 2 February 2019

\section{DESCRIPTION}

Congenital dermoid cysts occur at lines of embryological fusion due to ectoderm sequestration. Despite being congenital, dermoid cysts may not present until late childhood or even later. ${ }^{1}$

Implantation dermoids (epidermoid cysts) have different pathogenesis. They happen secondary to mechanical implantation of epidermis into the subcutaneous tissue secondary to injury or surgery.

The incidence of dermoid tumours is roughly 3 per 10,000 paediatric patients, with greater than $80 \%$ of paediatric dermoids occurring in the head and neck. ${ }^{2}$ Other sites include midline of the chest. Literature review shows case reports of exception to this rule, but no truncal non-midline lesions have been reported. ${ }^{34}$

A 14-year-old male patient presented to outpatient clinic with a painless swelling in left upper part of chest wall of 2 years duration. He had no history of previous injury or surgery to the site. He was otherwise fit and well.

Clinical examination revealed a $1 \mathrm{~cm}$ spherical swelling superficial to the left 1 st intercostal space $4 \mathrm{~cm}$ from midline (figure 1). The swelling was soft,

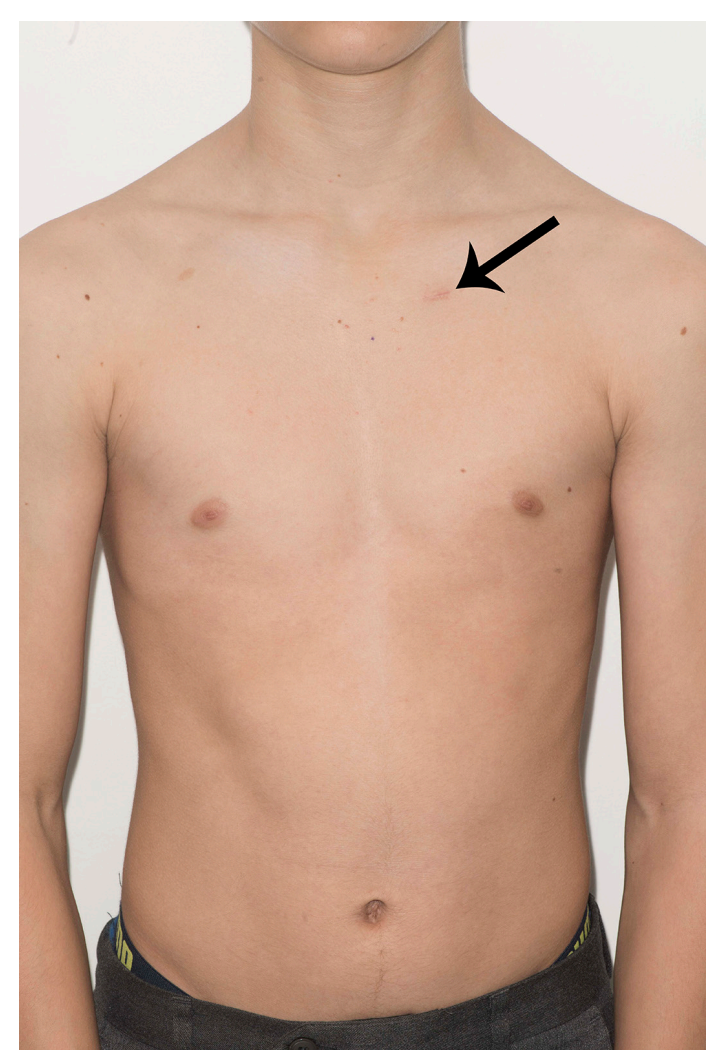

Figure 1 An arrow is pointing to location of the cyst on chest wall.

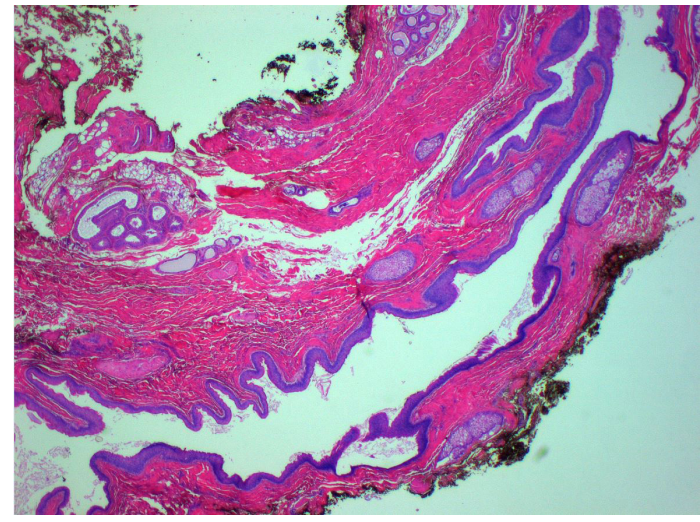

Figure 2 Histological features of the excised cyst.

mobile, not tender and not tethered to skin or deep structures. The overlying skin was unremarkable. There were no other swellings or palpable lymphadenopathy. A provisional diagnosis of a lipomatous tumour was made.

Complementary ultrasound scan was requested but was unfortunately indeterminate, and a specific diagnosis could not be made.

The decision was made to excise the lump under local anaesthesia.

Intraoperatively, a transverse incision was made over the lump. The lump was accidentally punctured by the blade. Expressing the lump contents, that is, creamy material and hair.

The lump was completely excised and sent for histopathology.

The analysis of lump revealed ruptured cyst containing some keratin. Adjacent to the cyst, there were skin adnexal structures such as sebaceous glands and sweat glands. There was no significant adipose tissue (figure 2). The features were consistent with the congenital dermoid cyst. ${ }^{4}$ Implantation dermoids have no adnexal structures and,

\section{Patient's perspective}

I am mother of the patient and my son gives permission and consent for this publication. I am eager to get it published as a rare incident.

\section{Learning points}

- Dermoid cysts scan present in unusual places.

- Unusual places can be due to migration of the cyst or atypical embryological fusion lines.

- Dermoid cysts may present in late childhood. 
therefore, they are easily distinguished from congenital dermoid cysts on histology.

Dermoids occurring outside classical embryological fusion lines are not described. This has occurred at the junction between cervical and thoracic innervated tissue, but this is not understood to be an embryological fusion line. We are not sure if this cyst had migrated from midline. As such it is interesting, and a potential diagnosis for paediatric surgeons to be aware of.

Contributors MM has written up the manuscript after fulfilling all requirements. EG had reported the specimen and reviewed the pathology report. EW was the main operating surgeon and manuscript final reviewer.

Funding The authors have not declared a specific grant for this research from any funding agency in the public, commercial or not-for-profit sectors.
Competing interests None declared.

Patient consent for publication Obtained.

Provenance and peer review Not commissioned; externally peer reviewed.

\section{REFERENCES}

1 Smirniotopoulos JG, Chiechi MV. Teratomas, dermoids, and epidermoids of the head and neck. Radiographics 1995;15:1437-55.

2 Orozco-Covarrubias L, Lara-Carpio R, Saez-De-Ocariz M, et al. Dermoid cysts: a report of 75 pediatric patients. Pediatr Dermatol 2013;30:706-11.

3. Fried MP, Vernick DM. Dermoid cyst of the middle ear and mastoid. Otolaryngol Head Neck Surg 1984;92:594-6.

4 Linnard H, Newman L, Barrett AW. British Journal of Oral and Maxillofacial Surgery. 2017:55:983-4

5 Reissis D, Pfaff MJ, Patel A, et al. Craniofacial dermoid cysts: histological analysis and inter-site comparison. Yale J Biol Med 2014;87:349-57.

Copyright 2019 BMJ Publishing Group. All rights reserved. For permission to reuse any of this content visit

https://www.bmj.com/company/products-services/rights-and-licensing/permissions/

BMJ Case Report Fellows may re-use this article for personal use and teaching without any further permission.

Become a Fellow of BMJ Case Reports today and you can:

- Submit as many cases as you like

- Enjoy fast sympathetic peer review and rapid publication of accepted articles

- Access all the published articles

Re-use any of the published material for personal use and teaching without further permission

For information on Institutional Fellowships contact consortiasales@bmjgroup.com

Visit casereports.bmj.com for more articles like this and to become a Fellow 